\title{
Julián Fuks e a imprescindível arte de resistir
}

\author{
FUKS, Julián. A resistência. São Paulo: Companhia das Letras, 2015.
}

Natali Fabiana da Costa e Silva ${ }^{1}$

http://lattes.cnpq.br/4523010397725244

Enviado em: 19/09/2018

Aceito em: 23/01/2019

Publicada em 2015, a obra $A$ resistência, de Julián Fuks, se inscreve na perspectiva da memória e revela um complexo jogo entre ficção e realidade. Foi qualificada pelos críticos literários como autoficção porque "rompe com o princípio de veracidade" sem, contudo, “aderir integralmente ao princípio da invenção" (FAEDRICH, 2015, p.46). É nessa intersecção entre o real e o ficcional que o narrador Sebastián, no ato de escrever um livro sobre seu irmão adotivo, tece nas malhas da narrativa sua vida familiar, o período turbulento da ditadura, o exílio dos pais, que tiveram de deixar a Argentina devido à perseguição política. Na convergência entre o "verdadeiro" e o "fabuloso", escritor e narrador se confundem e a ficção coteja a realidade, pois Fuks, nascido em São Paulo em 1981, é filho de argentinos exilados e também tem um irmão adotado.

A narrativa abre com uma epígrafe "Creo que hay que resistir: éste há sido mi lema. Pero hoy, cuántas veces me he preguntado como encarnar esta palavra.". O excerto, da autoria de Ernesto Sabato, parece guiar as reflexões na obra de Fuks e, assim, a resistência, destacada inclusive pelo título do livro, presentifica-se desde os temas escolhidos até o próprio ato da escrita, uma vez que, segundo Bosi (1996, p.13), "a resistência se dá como processo inerente à escrita".

Os temas abordados ou, ainda, as reflexões que o narrador enceta são transpassados pela resistência enquanto motor de ação, pois o mote da narrativa, que é escrever sobre o irmão adotado, traz em seu bojo distintos aspectos sociais e históricos que ele articula à luz do contexto atual.

É da tentativa de compreender esse irmão que ao longo dos anos foi se afastando da família, indiferente à cumplicidade doméstica, que três outros assuntos despontam: a repressão política, o resgate da memória e a compreensão de si por meio da escrita. Todas essas questões se imbricam, a começar pela adoção, vista pelo narrador como um ato de resistência, conforme ele afirma:

Talvez o desejo de ter um filho fosse naquele instante o que lhe restava de vida, fosse outra forma de luta, de recusa à aniquilação proposta pelo regime. Ter um filho há de ser, sempre, um ato de resistência. Talvez a afirmação da continuidade da vida fosse apenas mais um imperativo ético a ser seguido, mais um modo de se opor à brutalidade do mundo. (FUKS, 2015, p.42).

O extermínio de homens ocorrido durante os anos de chumbo não poderia ter sido melhor combatido que com a decisão pela vida. O filho mais velho é, então, elevado da categoria de primogênito para simbolizar, perante os olhos do irmão mais novo, a

\footnotetext{
1 Professora Doutora da Universidade Federal do Amapá (UNIFAP) e coordenadora do Núcleo de Pesquisas em Estudos Literários (NUPEL). E-mail: natali costa@hotmail.com
} 
resistência em si. Entretanto, esse mesmo irmão, signo de insubmissão ao regime ditatorial, é também aquele que não se adequa aos ritos familiares, que se insubordina às regras da casa e, então, se exila na solidão de seu quarto.

O narrador parece afirmar que nenhuma definição é simples, que a narrativa que nos define depende da construção de um discurso que, por sua vez, apoia-se em perspectivas, escora-se no escorregadio tecido da memória, firma-se sobre conceitos fugidios, repousa sobre o indizível. Nesse sentido, as reflexões sobre o irmão mais velho baralham a compreensão de Sebastián, que não logra entender seu alheamento voluntário e confessa: "falei do temor de perder meu irmão e sinto que o perco a cada frase." (FUKS, 2015, p.23).

Ao mesmo tempo, na fracassada busca do irmão, Sebastián encontra-se a si, inscrevese como continuidade da história dos pais, preenche as lacunas que o passado deixou pendente: "É preciso aprender a resistir. Nem ir, nem ficar, aprender a resistir. Penso nesses versos que meu pai não poderia ter pensando, versos inescritos na época, versos que lhe faltavam.” (FUKS, 2015, p.79). O narrador percebe-se, também, pela perspectiva histórica e, nesse sentido, encontra-se num entendimento avesso ao entendimento paterno, na compreensão pela diferença: "Tenho a idade que meu pai tinha naquela época - o bastante para saber que as armas dele não são as minhas, que não me cabe querer empunhá-las e fazer dele um irmão em armas, que só me resta sondar conceitos, tentar compreendê-las." (FUKS, 2015, p.39).

É interessante perceber como os dramas pessoais não se descolam da perspectiva histórica. Sebastián inicia assim um de seus capítulos: "Isto não é uma história. Isto é história" (FUKS, 2015, p.23). A adoção, por exemplo, para além de revelar um ímpeto de resistência por parte dos pais desvela os procedimentos realizados na Argentina à época do regime ditatorial. Não era incomum, segundo denuncia o narrador, que os militares tirassem os filhos recém nascidos das prisioneiras políticas. As crianças, tão logo nascessem, eram entregues a outras famílias. Por conta dessa prática, surgiu o grupo das "Avós argentinas com netos desaparecidos". Eram uma facção das "Madres da Praça de Maio", mulheres que lutam para saber o paradeiro de seus entes queridos.

A adoção do irmão mais velho de Sebastián, ocorrida em Buenos Aires antes do exílio dos pais, passa a gerar desconfiança no narrador. Embora conheça os relatos sobre a adoção, ele resvala em dúvidas, questiona o que lhe foi contato. O processo de rememoração e reflexão que o envolve a partir de então arremessa-o a terrenos incertos "Há muitas coisas que não quero voltar a perguntar, que prefiro evocar de palavras guardadas na obscuridade da memória, palavras que já esqueci mas que minha mente cuidou de transformar em vagas noções, turvas imagens, impressões duvidosas.” (FUKS, 2015, p.90).

Isso ocorre, pois no processo de escrita de Sebastián, suas memórias se confundem com as histórias vividas por seus pais e por ações de outrem praticadas em um espaçotempo no qual ele sequer esteve presente:

Caminho pelas ruas de Buenos Aires e vou parar na praça do Congresso, em frente à sede das Mães da Praça de Maio. Hesito um instante na porta, não me decido a entrar. Já estive ali outras vezes por mero turismo ou curiosidade, já percorri cada estante da livraria, já tomei um café em sua galeria, já me deixei impregnar por seus testemunhos, suas histórias, suas palavras de ordem. (FUKS, 2015, p.19).

Esse processo é o que Halbwachs (2006) denomina memória coletiva. Para o filósofo e sociólogo francês, a memória não fica restrita ao mundo da pessoa, mas depende do 
relacionamento com sua família, com o grupo social que a cerca e com outros grupos de referência peculiares a esse sujeito.

Coaduna com essa ideia Gagnebin (2005), para quem não se pode subtrair memória individual da memória coletiva, pois, a memória é impregnada ou transpassada pelo meio social do qual o indivíduo faz parte. Isso leva à questão da identidade, pois para Gagnebin, sua construção implica a narração de si mesmo. Essa narração, por sua vez, é constituída a partir de histórias diversificadas do indivíduo e de sua participação da vida mais ampla.

Em $A$ resistência, a narrativa se articula à medida que se deixa atravessar pela memória coletiva a qual, aos poucos, tece a história de Sebastián. É desse modo que as memórias oriundas dos anos de chumbo e da experiência familiar, constroem a identidade do narrador no momento da enunciação, mesmo que ele não tenha vivenciado diretamente esses acontecimentos.

$\mathrm{Na}$ tentativa de falar do irmão, o narrador constrói paradoxalmente uma narrativa de si. Resgata as memórias para, quem sabe, numa atitude semelhante àquela de Dom Casmurro, unir as duas pontas da vida: o passado e o presente. É no ato da escrita que ele se compreende e percebe que suas noções, suas impressões e mesmo suas memórias estão sujeitas à ressignificação, pois retornar ao passado não significa conhecê-lo tal qual ele foi, "significa apropriar-se de uma reminiscência, tal como ela relampeja no momento de um perigo” (BENJAMIN, 1994, p.224). Sebastián está ciente dessa condição:

$\mathrm{Na}$ minha lembrança os olhos do meu irmão estavam lacrimosos, mas desconfio que essa seja uma nuance inventada, acrescida nas primeiras vezes que rememorei o episódio, turvado já por algum remorso. Ele estava sentado no banco da frente. Se chorava, decerto continha qualquer soluço e escondia as lágrimas com as mãos; ou voltava o rosto para a janela, extraviava a vista em presumíveis pedestres. O caso é que não me olharia, não viraria para trás. Talvez fossem os meus, os olhos lacrimosos, (FUKS, 2015, p.14).

Todorov afirma que "todo ato de reminiscência, por mais humilde que seja, é associado com a resistência antitotalitária" (2000, p.14)². Assim é constituído o romance de Fuks, que se erige enquanto resistência inclusive na forma literária. $\mathrm{Na}$ obra, a escrita se funda no paradoxo: a tentativa de se lembrar dos acontecimentos lança o narrador às incertezas da memória; a escrita que deveria servir para encontrar o irmão, acaba por fazê-lo encontrarse a si mesmo; a busca de uma narrativa penetrada pela História, imbuída de fatos o faz perceber que o que tem a seu dispor não são mais que "noções fugazes, impressões anteriores à consciência e à linguagem" (FUKS, 2015, p.23). Nesse paradoxo, conclui que as palavras se tornam indizíveis e, por isso, calar não é trair, é, antes, resistência.

Fuks parece afirmar sobre a impossibilidade de pensar o presente sem recorrer às gerações antepassadas, às ideologias, às convicções e aos princípios de um dado povo em um dado momento. Em outras palavras, para o autor, a História não está limitada ao pretérito: ela resiste porque o indivíduo, quando se percebe sujeito histórico, é capaz de promover transformações.

Sebastián se descobre como esse sujeito ao longo da narrativa. Compreende que a realidade que vive não é distinta da de seus pais: "As ditaduras podem voltar, eu sei, e sei que seus arbítrios, suas opressões, seus sofrimentos, existem das mais diversas maneiras, nos

${ }^{2}$ Tradução do original: "por qué todo acto de reminiscencia, por humilde que fuese, há sido associado com la resistencia antitotalitaria".

https://periodicos.unifap.br/index.php/letras

Macapá, v. 8, n. 3, $2^{\circ}$ sem., 2018 
mais diversos regimes, mesmo quando uma horda de cidadãos marcha às urnas bienalmente.” (FUKS, 2015, p.40). O que o difere de seus pais é a arma escolhidas para o embate, a escrita: essa, a sua "integridade".

A leitura de $A$ resistência mostra que as memórias, mesmo aquelas não vivenciadas pela própria experiência, são capazes de moldar nossa existência, que o retorno ao passado não é uma jornada longa, ainda que se mudem algumas perspectivas, e que o combate à opressão e à desigualdade pode se dar de várias formas.

Retomando o jogo entre ficção e realidade contido na obra, para ambos os escritores, Fuks e Sebastián - aquele cotejado pela personagem ficcional -, é na literatura, incontestável lugar da fantasia, que a verdade mais exigente pode ser encontrada. Finalmente, A resistência revela que por meio da ficção se "descobre a vida verdadeira" (BOSI, 1996) e que o romance deve resistir (e resiste) enquanto forma estética e enquanto instrumento de humanização.

\section{Referências}

BENJAMIN, W. Magia e técnica, arte e política: ensaios sobre literatura e história da cultura. 7. ed. Tradução de Sérgio Paulo Rouanet. São Paulo: Brasiliense, 1994.

BOSI, Alfredo. Narrativa e resistência. Itinerários, Araraquara, n. 10, p.11-27,1996. Disponível em: <http://seer.fclar.unesp.br/itinerarios/article/viewFile/2577/2207>. Acesso em: 14 jul. 2017.

FAEDRICH, Anna. O conceito de autoficção: demarcações a partir da literatura brasileira contemporânea. Itinerários, Araraquara, n. 40, p.45-60, jan./jun., 2015. Disponível em: $<$ http:// seer.fclar.unesp.br/itinerarios/article/viewFile/8165/5547>. Acesso em: 14 jul. 2017.

FUKS, Julián. A resistência. São Paulo: Companhia das Letras, 2015.

GAGNEBIN, Jeanne-Marie. Sete aulas sobre linguagem, memória e história. Rio de Janeiro: Imago, 2005.

HALBWACHS, Maurice. La mémoire collective. Paris: PUF, 1950.

TODOROV, Tzvetan. La memoria amenazada. In: ___ Los abusos de la memoria. Tradução do francês de Miguel Salazar. Barcelona: 2000. p.11-15. 